\title{
CEsifo WORKING

\section{Local Economic Consequences of Investment in Children: Capitalization of Child Care Services}

Lars-Erik Borge, Jørn Rattsø 


\section{Impressum:}

CESifo Working Papers

ISSN 2364-1428 (electronic version)

Publisher and distributor: Munich Society for the Promotion of Economic Research - CESifo $\mathrm{GmbH}$

The international platform of Ludwigs-Maximilians University's Center for Economic Studies and the ifo Institute

Poschingerstr. 5, 81679 Munich, Germany

Telephone +49 (o)89 2180-2740, Telefax +49 (o)89 2180-17845, email office@cesifo.de

Editors: Clemens Fuest, Oliver Falck, Jasmin Gröschl

www.cesifo-group.org/wp

An electronic version of the paper may be downloaded

- from the SSRN website: $\quad$ www.SSRN.com

- from the RePEc website: $\quad$ www.RePEc.org

- from the CESifo website: www.CESifo-group.org/wp 


\title{
Local Economic Consequences of Investment in Children: Capitalization of Child Care Services
}

\begin{abstract}
Recent analyses of intergenerational mobility show that investments in children pay big dividends. The priority of resources in early childhood also affects the working of the local economy. Geographic variation in child care services motivates location of families and thereby influences housing markets. In this paper we analyze this local dimension of universal child care during a period of national reform to raise and equalize the child care coverage across Norway. We apply a rich dataset of housing transactions and characteristics for six years (2001-2006) and combine them with local government level data about quantity and quality of child care and various community controls. Given a reform driving the expansion of child care coverage with central government financing, we investigate the relationship between child care and housing prices using a variety of panel models. The robustness of the results are studied under the stronger assumption that only changes in coverage were mandated. The results show that housing prices respond to child care and are consistent with the recent literature on capitalization of schooling. In the first difference model, $10 \%$ increase in child care coverage, about one standard deviation, raises house prices by 3\%. We conclude that child care reform initiates adjustments at housing markets and confirms the role of geographic sorting as part of local fiscal allocations.
\end{abstract}

JEL-Codes: H710, H750, R210, R230, R320.

Keywords: capitalization, child care, housing prices, local government.

\author{
Lars-Erik Borge \\ Department of Economics \\ Norwegian University of Science and \\ Technology \\ Norway-7491 Trondheim \\ larseb@svt.ntnu.no
}

\author{
Jørn Rattsø \\ Department of Economics \\ Norwegian University of Science and \\ Technology \\ Norway-7491 Trondheim \\ jorn.rattso@ntnu.no
}

The research is financed by the Research Program Democracy and Regional Development (DEMOS) by the Norwegian Research Council. We appreciate discussions and comments at the 2017 IIPF congress in Tokyo, the 10th Norwegian-German Seminar on Public Economics, as well as from seminars at Umeå University and the Norwegian Business School (BI). 


\section{Introduction}

Recent research on intergenerational mobility shows the importance of investing in children Chetty et al. (2011) presents convincing evidence and overview of results. The literature applies rich register data to study how schools contribute to educational and economic outcomes of the children. Jackson et al. (2015) summarize the conflicting evidence regarding school spending effects. Langørgen and Løkken (2017) find that school spending in Norway raises future wages for some children when looking into the heterogeneity of effects. The new analyses add qualitative and quantitative aspects of schooling.

The attention has shifted somewhat from schools to child care - early interventions may have even stronger effects. Baker (2011) discusses the evidence comparing targeted interventions and universal child care. The literature has dealt with both child care subsidies and universal child care programs. Black et al. (2014) find a positive effect of child care subsidies on school performance. The analyses of universal child care have not reached common conclusions about the consequences for children's performance, but Havnes and Mogstad (2015) show positive long-term effects on earnings using data for Norway. The main identification challenge for the analysis of child care effects for intergenerational mobility is the geographical sorting of families. Residential mobility is part of the responses to changes in child care services. The mobility influences housing markets and allows for a valuation of the services in question. In this paper we study the local adjustment mechanisms to investment in children - the relationship between (expansion of) universal child services and housing prices in Norway during a period of child care reform.

The capitalization literature related to investment in children mainly covers the effects of schooling. Black (1999) innovated this literature by studying school quality effects on house prices by exploiting boundary discontinuities. Further analyses have investigated organization and quality of schools, such as Figlio and Lucas (2004) and Clapp et al. (2008). Recent studies of 'information shocks' about quality include Fiva and Kirkebøen (2011) and Imberman and Lovenheim (2016). Machin and Salvanes (2016) take benefit of a school admission reform changing the role of boundaries between school districts. We do not know of any studies of capitalization of child care services, but our approach is similar to the many analyses of schools. Borge and Rattsø (2014) include child care services in an analysis concentrating on property tax capitalization. 
Capitalization was introduced as a test of the underlying mechanisms of the Tiebout-model (Tiebout 1956) where competition and mobility between local governments lead to efficient resource allocation under specific assumptions. The hypothesis of property tax capitalization was first developed and tested by Oates (1969). Brueckner (1982) derived and tested an efficiency conditions related to the maximization of property value in the community. Later studies have questioned capitalization as a test of economic efficiency, as discussed by Hilber (2017).

The analysis of capitalization also offers information about government behavior. Wallis et al. (1994) develop the 'fiscal interest approach' further assuming that public officials prefer policies that relax their budget constraint. Fischel (2001a, 2001b) introduces the concept of 'homevoters', homeowners whose voting is guided by their concern for home values. To protect property values, homevoters will put great pressure on local governments to provide services efficiently. Dehring et al. (2008) presents empirical evidence in support of the homevoter hypothesis. Hilber and Mayer (2009) show that even voters not directly affected by the local public services care about them - 'why do households without children support local public schools?'. Ross and Yinger (1999) summarize the literature on sorting and voting.

In the European countries child care typically is under the responsibility of local governments and with central government financing as general and specific grants in addition to the payments of parents. The standard approach is to study demand for various services taking into account the budget constraint of the local government. The Norwegian setting is described and analyzed by Borge et al. (2014). The importance of fiscal competition has previously been shown by Carlsen et al. (2005) in an analysis of the relationship between firm mobility and infrastructure fees. Local governments with high firm mobility have lower fee level. Carlsen (2005) examines the effects of local fiscal variables and local economic conditions on migration plans of Norwegian households. His analysis confirms the importance of local services for migration plans and opens up for the possibility of capitalization effect of the services. Related to this paper and using the same housing data Carlsen et al. (2009) offer a first analysis of capitalization using information from household surveys. Interviews about household satisfaction with local services are used to analyze the relationship between services satisfaction and housing prices. The contribution is a response 
to the literature struggling with input and output measures of services and shows that satisfaction is associated with housing prices.

The overview of capitalization studies by Ross and Yinger (1999) is critical to the use of public spending per capita as a measure of public service quality. We must look for characteristics of the services important for the utility of the households. The present analysis makes use of detailed statistics available to describe quantity (coverage) and quality (children per employee, education level of employees) of universal child care.

We take benefit of a national child care reform to expand universal child care coverage in Norway. The parliament agreed in 2003 to a policy to secure 'full coverage' of child care - all parents demanding a place at the regulated price should get it. The central government provided plans and financing for the program to expand child care coverage, and the local governements were responsible for the implementation. The main analysis assumes that the child care coverage during the implementation was mandated and determined by reform. However, given the local government responsibility of the provision and different histories of child care services, we do not have a 'clean' natural experiment. Local economic, social and political conditions may have influenced the development of child care coverage. In this case, the OLS estimates may have bias reflecting the standard identification challenges related to endogeneity and omitted variables. We investigate the role of other factors in a series of specifications. In particular we also estimate a first-difference form of the model where only changes in child care coverage is assumed mandated. The results are quite consistent across alternative model formulations.

The panel analysis confirms the role of the housing market in the local fiscal adjustment to child care services. Housing prices do respond to child care coverage. The preferred panel model implies that $10 \%$-points increase in child care coverage, about one standard deviation, raises housing prices by $5 \%$. In the first difference version of the model assuming that mandating only affects changes in coverage the house price effect is $3 \%$. The size of the effects is consistent with the literature estimating capitalization of schooling. These studies find that one standard deviation difference in test scores is associated with $2-5 \%$ higher property values (see overview of Black and Machin, 2011). We conclude that child care reform initiates adjustments at housing markets and confirms the role of geographic sorting as part of local fiscal allocations. 
The next section presents data and econometric specifications. The main analysis of capitalization is presented in section 3. Section 4 inestigates a first-difference version of the model. Concluding remarks are offered in section 5.

\section{Data and econometric formulation}

This study of capitalization effects of local public services focuses on child care services. Child care is assumed important for the migration of young families and therefore important for the housing market. In the empirical analysis we concentrate on formal child care institutions that comply with national law and regulations and receives public subsidies. ${ }^{1}$ The law requires that the institutions must have an educated preschool teacher as a leader, and there are also regulations on educational content for the children, group size, physical environment, and formal skills of the staff. ${ }^{2}$ Formal child care institutions are either owned and operated by local governments or by private organizations and firms. There is a large number of private child care institutions in Norway, and the distribution between public and private is roughly 50-50. Both public and private child care centers are jointly financed by the national government, local governments and parents. Since 1975 child care has been a local government responsibility.

By the turn of the century the typical situation was waiting lists and rationing of formal child care. In 2003 the national government initiated a child care reform. The background for the reform was concern regarding insufficient and geographical variation in coverage (children in child care centers as share of the number of children), high user fees and low local government subsidies for private child care centers. National limit on user fees and regulation of local government subsidies of private child care centers were introduced. The reform was financed by earmarked grants from the central government.

In the empirical analysis we use five indicators for quantity and quality of child care services. The first indicator of quantity is child care coverage for children aged 1-5 years. As discussed above, coverage includes both public and private child care centers. Table 1 shows that the

\footnotetext{
${ }^{1}$ Informal child care include nannies, relatives and friends.

${ }^{2}$ We refer to Havnes and Mogstad (2011a, 2011b, 2015) for more details on child care in Norway.
} 
coverage increased steadily during the period under study, from 66.5 percent in 2001 to 82.3 percent in 2006. Both public and private child care centers expanded, roughly in tandem. Although the variation in coverage across local governments was reduced, the variation was substantial also by the end of the period. In 2006 coverage varied from 56.6 percent to 100 percent. $^{3}$

\section{Table 1}

The indicators of child care services, 2001-2006

\begin{tabular}{|l|c|c|c|c|c|}
\hline Year & $\begin{array}{c}\text { Coverage } \\
1-5 \text { years }\end{array}$ & $\begin{array}{c}\text { Coverage } \\
\text { 1-2 years }\end{array}$ & $\begin{array}{c}\text { Coverage } \\
\text { 3-5 years }\end{array}$ & $\begin{array}{c}\text { Children per } \\
\text { man-year }\end{array}$ & Education \\
\hline 2001 & 0.665 & 0.400 & 0.834 & 7.5 & 0.297 \\
& $(0.114)$ & $(0.158)$ & $(0.109)$ & $(1.42)$ & $(0.073)$ \\
\hline 2002 & 0.692 & 0.428 & 0.859 & 7.4 & 0.300 \\
& $(0.112)$ & $(0.161)$ & $(0.103)$ & $(1.28)$ & $(0.076)$ \\
\hline 2003 & 0.721 & 0.455 & 0.879 & 7.4 & 0.312 \\
& $(0.105)$ & $(0.157)$ & $(0.095)$ & $(1.18)$ & $(0.070)$ \\
\hline 2004 & 0.752 & 0.497 & 0.905 & 7.2 & 0.314 \\
& $(0.095)$ & $(0.152)$ & $(0.082)$ & $(1.09)$ & $(0.073)$ \\
\hline 2005 & 0.781 & 0.550 & 0.925 & 7.1 & 0.319 \\
& $(0.088)$ & $(0.150)$ & $(0.076)$ & $(1.14)$ & $(0.081)$ \\
\hline 2006 & 0.823 & 0.636 & 0.941 & 6.9 & 0.310 \\
& $(0.075)$ & $(0.131)$ & $(0.061)$ & $(0.96)$ & $(0.079)$ \\
\hline
\end{tabular}

Note: Means with standard errors in parentheses. Coverage and education are measured on a $0-1$ scale. Children per man-year is age-adjusted taking into account that younger children are more resource demanding.

The shortage of child care places was most severe for younger children, and it is of interest to separate between younger (1-2 years) and older (3-5 years) children. It can be seen from Table 1 that coverage is lower for younger children, but the increase in coverage is much larger for this group. However, the variation in coverage across local governments was not much reduced for the younger children.

In addition to coverage, we include two indicators of quality. These are the number of children in child care centers per man-year (inversely related to quality) and the share of the staff educated as preschool teachers. Children per man-year is age adjusted and takes into account that younger children requires more staff. If had it not been age adjusted, the increase in quality would have been overrated due to the change in age composition towards more resource demanding younger children. Due to lack of data for private child care centers, the

\footnotetext{
${ }^{3}$ The coverage rate in the official statistics is above 100 percent in a few local governments because children from neigboring local governments use the child care centers. In the empirical analysis coverage is set to 100 percent in these cases.
} 
indicators of quality only capture public child care centers. The number children per man-year dropped from 7.5 in 2001 to 6.9 in 2006, indicating a substantial increase in quality. Also the variation across local governments was reduced. On the other hand, the increase in the share of the staff educated as preschool teachers was more modest.

Coverage and quality of child care are measured at the local government level. This is appropriate in the Norwegian context where there are no catchment areas as in the school sector. Parents may want a child care place near their home or work place, but the allocation is determined by the local governement. They must accept a place wherever they are offered one. Consequently, aggregate measures at the local government level are good indicators of the probability of getting a place and the quality if they get a place.

Our working hypothesis is that parents value high probability of getting a place in high quality child care, and that they are willing to pay more for a house in a municipalities with high coverage, few children per man year and a well educated staff. In order to test this capitalization hypothesis, we utilize a dataset covering all housing transactions in Norway during 2001-2006.

The dataset covers Norwegian housing transactions during 2001-2006 and provides information about price, square meters, and type of house. After excluding extreme observations with respect to size and price per $\mathrm{m}^{2}$, we are left with a data set of around 307,000 observations.

The data of housing prices are documented in Appendix A. In the tables A1 and A2 housing prices are grouped by municipal population size and part of the country. We also separate between three types of houses; detached houses, semi-detached or row houses, and apartments. From 2001 to 2006 the average increase in nominal housing prices was 49-56 percent. By comparison the consumer price index increased by 8.3 percent during the same period, yielding a real housing price growth of 38-44 percent. House prices are clearly higher in urban areas (larger municipalities, the capital area) than in rural areas (small municipalities, east inland, and the northern part of the country). These differences widened during the period under study as the areas with the highest housing prices at the outset also experienced the highest growth in housing prices. 
We follow the standard approach and estimate a linear appproximation assuming that the interest rate is constant. The main shortcoming with this formulation is that the degree of capitalization will vary with housing value. The homogeneity of the housing standard in our data reduces this problem. For convenience we use a semi-log form and indexed for house $h$ in local government $i$ in year $t$ :

$\log \left(V_{h i t}\right)=\beta_{t}+\beta_{1} C C_{i t}+\beta_{2} O S_{i t}+\beta_{3} H_{h i t}+\beta_{4} A_{i t}+u_{h i t}$

where $V_{h i t}$ is the measured market price of house transactions, $C C_{i t}$ a vector describing child care services, $O S_{i t}$ represent other services, $H_{h i t}$ is a vector of housing characteristics, $A_{i t}$ a vector of amenities and $u_{i t}$ an error term. The data for housing prices, housing characteristics and the indicators of child care services are described above. In the following we discuss other services and amenities. ${ }^{4}$

The financing of Norwegian local governments is quite centralized, and the revenues are dominated by general purpose grants and regulated income and wealth taxes (where all local governments apply the maximum rates). The local public services are subject to national mandating to have equalization of service levels across the country. It should be noticed that quality aspects of the services do not necessarily represent permanent characteristics that the housing market will capitalize to much extent. We use local government revenues per capita as a control variable to represent quantity and quality of other local public services. The revenues are adjusted for variation in spending needs using the criteria in the spending needs equalization system. In addition we include school expenditures per pupil to take account of possible correlation between resource use on child care and primary and lower secondary education.

Whereas the typical U.S. analysis uses data for a cross section of communities within a narrow geographical area that share a common labor market, a Norwegian analysis can rely on data for a larger geographical area comprising several labor markets. The variation is larger, but so is the heterogeneity. Extending the analysis to a larger geographical area and several labor markets makes the estimation of capitalization more challenging as the number of elements in the measurement of amenities will increase substantially. A large number of

\footnotetext{
${ }^{4}$ Descriptive statistics are reported in appendix E.
} 
controls are included to capture local amenities. The municipal unemployment rate is included to represent local labor market conditions, while the population size, age composition and the settlement pattern are included to capture housing market conditions. The role of climate, shown to be important in US studies, is captured by a measure of the average winter temperature during 1971-2000.

Finally, we include fixed effects for centrality and labor market region. Centrality is based on a classification developed by Statistics Norway where the 435 local governments are divided into 7 groups depending on the travel distance to regional centers with specific functions. Labor market regions are based on a classification made by Statisics Norway (Bhuller 2009) based on travel-to-work patterns. The country is divided into 46 labor market regions.

The models are estimated by pooled OLS because of the short time series. It is well known that pooled regressions may underestimate the standard errors and thereby overestimate the tvalues, see Wooldridge (2003). To avoid this problem we report t-values based on clustered standard errors taking into account that error terms from the same municipality are correlated. In the regressions we always include the full set of housing characteristics and year and month fixed effects to represent common shocks. Given that the statistical inference must be based on cross section variation, we investigate the robustness of the results using alternative formulations for the structural characteristics capturing labor and housing markets and the difference between urban and rural municipalities. As additional robustness checks we perform year-by-year regressions, exclude small and large municipalities, and estimate separate regressions for the three types of houses.

The main analysis assumes that the development of child care services is determined by national reform. As discussed in the introduction, the national reform has set plans and financing for expansion of child care services, and the implementation has been the responsibility of local governments. The expansion of child care was mandated to secure full coverage in all municipalities. However, local economic, social and political conditions with different histories of child care services may have influenced the implementation. The standard sources of biased coefficients resulting from endogeneoty and omitted variables cannot be ruled out. To check for these identification problems, we estimate the model on first difference form assuming that the mandating was restricted to the change of child care coverage. 


\section{Capitalization of child care coverage driven by reform}

The pattern in the data are studied with pooled regressions for the dataset covering about 307,000 house transactions and most of the 435 municipalities during 2001-2006. The main results are presented in Table 2. The first basic regression in column A shows the 'raw' effect of child care coverage only taking into account housing characteristics and year and month fixed effects. The housing characteristics come out with reasonable effects (Appendix B). Size comes out as positive and significant, while size squared is significantly negative as expected. Given that size is controlled for, semi-detached house and apartments have higher prices than detached houses.

The estimate of the 'raw' model in column A implies that an increase in share of child care coverage by $10 \%$-points is associated with $7.5 \%$ higher house prices on average, statistically significant at $1 \%$ level. In the following we expand the model in two dimensions - first to include more controls taking into account other factors influencing housing prices and narrowing down the comparisons, second to extend the description of child care services.

Column B of Table 2 shows the main battery of controls applied. Characteristics of municipalities observed over time include population size, age composition of the population, share of population in rural areas, unemployment rate, and winter temperature to account for other determinants of housing market performance. Unemployment and high share of rural population are associated with lower housing prices, while prices are higher in municipalities with large populations, typically cities. Population size and population density are strongly correlated in the data. A mild climate (high winter temperature) has a positive effect on housing prices. In column B we also include labor market area and centrality group fixed effects. This narrows down the comparison to municipalities within the same labor market area and with similar housing markets. Including this battery of controls the estimated capitalization coefficient is 0.672 . A $10 \%$-point increase in child care coverage raises the housing price by about $6.7 \%$ on average. 
Table 2

Pooled regression results, 2001-2006

\begin{tabular}{|c|c|c|c|c|c|c|}
\hline & $\mathrm{A}$ & $\mathrm{B}$ & $\mathrm{C}$ & $\mathrm{D}$ & $\mathrm{E}$ & $\mathrm{F}$ \\
\hline \multicolumn{7}{|l|}{ Child care indicators } \\
\hline Child care coverage $1-5$ year & $\begin{array}{l}0.754 \\
(2.96)\end{array}$ & $\begin{array}{l}0.672 \\
(7.00)\end{array}$ & & & $\begin{array}{l}0.536 \\
(6.14)\end{array}$ & $\begin{array}{l}0.514 \\
(5.48)\end{array}$ \\
\hline Child care coverage, $1-2$ year & & & $\begin{array}{l}0.212 \\
(3.16)\end{array}$ & $\begin{array}{l}0.207 \\
(2.43)\end{array}$ & & \\
\hline Child care coverage, $3-5$ year & & & $\begin{array}{l}0.416 \\
(3.15)\end{array}$ & $\begin{array}{l}0.368 \\
(2.71)\end{array}$ & & \\
\hline Children per man-year & & & $\begin{array}{c}-0.0429 \\
(-3.90)\end{array}$ & $\begin{array}{c}-0.0370 \\
(-3.23)\end{array}$ & $\begin{array}{l}-0.036 \\
(-3.25)\end{array}$ & \\
\hline $\begin{array}{l}\text { Share of staff with child care } \\
\text { education }\end{array}$ & & & $\begin{array}{c}-0.0793 \\
(-0.48)\end{array}$ & $\begin{array}{l}-0.0200 \\
(-0.13)\end{array}$ & & \\
\hline \multicolumn{7}{|l|}{ Other local public services } \\
\hline $\begin{array}{l}\text { Local government revenue } \\
\text { per capita }\end{array}$ & & & & $\begin{array}{l}0.365 \\
(3.57)\end{array}$ & $\begin{array}{l}0.344 \\
(3.67)\end{array}$ & $\begin{array}{l}0.377 \\
(3.60)\end{array}$ \\
\hline $\begin{array}{l}\text { School spending per pupil } \\
(\log )\end{array}$ & & & & $\begin{array}{l}-0.0109 \\
(-0.28)\end{array}$ & & \\
\hline \multicolumn{7}{|l|}{ Community characteristics } \\
\hline Population size (log) & & $\begin{array}{c}0.134 \\
(12.36)\end{array}$ & $\begin{array}{c}0.128 \\
(11.87)\end{array}$ & $\begin{array}{c}0.114 \\
(10.78)\end{array}$ & $\begin{array}{c}0.117 \\
(11.25)\end{array}$ & $\begin{array}{c}0.116 \\
(11.20)\end{array}$ \\
\hline Share of children & & $\begin{array}{l}4.69 \\
(2.48)\end{array}$ & $\begin{array}{c}4.39 \\
(2.52)\end{array}$ & $\begin{array}{c}4.23 \\
(2.58)\end{array}$ & $\begin{array}{c}4.12 \\
(2.62)\end{array}$ & $\begin{array}{c}4.52 \\
(2.58)\end{array}$ \\
\hline Share of elderly & & $\begin{array}{l}-2.75 \\
(-3.13)\end{array}$ & $\begin{array}{l}-2.59 \\
(-3.25)\end{array}$ & $\begin{array}{c}-2.72 \\
(-3.79)\end{array}$ & $\begin{array}{l}-2.73 \\
(-3.88)\end{array}$ & $\begin{array}{c}-2.84 \\
(-3.64)\end{array}$ \\
\hline $\begin{array}{l}\text { Share of population living } \\
\text { in rural areas }\end{array}$ & & $\begin{array}{l}-0.290 \\
(-4.90)\end{array}$ & $\begin{array}{l}-0.257 \\
(-4.23)\end{array}$ & $\begin{array}{l}-0.305 \\
(-4.97)\end{array}$ & $\begin{array}{l}-0.292 \\
(-5.29)\end{array}$ & $\begin{array}{l}-0.340 \\
(-6.00)\end{array}$ \\
\hline Unemployment rate & & $\begin{array}{l}-6.48 \\
(-4.11)\end{array}$ & $\begin{array}{l}-6.60 \\
(-4.88)\end{array}$ & $\begin{array}{l}-5.90 \\
(-5.18)\end{array}$ & $\begin{array}{l}-5.95 \\
(-5.18)\end{array}$ & $\begin{array}{l}-5.65 \\
(-4.29)\end{array}$ \\
\hline Winter temperature & & $\begin{array}{l}0.011 \\
(2.24)\end{array}$ & $\begin{array}{l}0.014 \\
(2.70)\end{array}$ & $\begin{array}{l}0.013 \\
(2.57)\end{array}$ & $\begin{array}{l}0.013 \\
(2.59)\end{array}$ & $\begin{array}{l}0.010 \\
(2.14)\end{array}$ \\
\hline Housing characteristics & Yes & Yes & Yes & Yes & Yes & Yes \\
\hline Year fixed effects & Yes & Yes & Yes & Yes & Yes & Yes \\
\hline Month fixed effects & Yes & Yes & Yes & Yes & Yes & Yes \\
\hline Centrality fixed effects & No & Yes & Yes & Yes & Yes & Yes \\
\hline Labor market fixed effects & No & Yes & Yes & Yes & Yes & Yes \\
\hline Number of municipalities & 412 & 411 & 410 & 407 & 410 & 411 \\
\hline Number of obs & 307,714 & 307,710 & 302,304 & 286,273 & 302,310 & 307,710 \\
\hline $\mathrm{R}^{2}$ & 0.398 & 0.686 & 0.688 & 0.689 & 0.689 & 0.687 \\
\hline
\end{tabular}


The child-care coverage varies across age groups of the children, and the coverage is lower and with larger variation and higher increase among the young children 1-2 years of age. It is of interest to investigate whether the coverage of young children has been more important for the location decision of families. In column $\mathrm{C}$ the coverage is separated for the 1-2 years old and the 3-5 years old, and we also include the two quality measures of child care. Child care coverage is positively related to housing prices for both age groups, and the estimate is highly significant for both groups. The effect of an increase in coverage by $10 \%$-points is $2.1 \%$ for the younger age group and $4.2 \%$ for the older age group. Both quantity and quality matters. A one standard deviation reduction in children per man-year increases housing prices by about $5 \%$. The education level of staff does not come out with any significant effect on house prices.

In column $\mathrm{D}$ the model is expanded further to characterize other local public services. Local government revenue per capita represent the overall level of local public services and always comes out with some positive effect on housing prices. Local government revenue is strongly regulated and consists mainly of general grants and regulated income tax sharing. We also include school spending per pupil in this model. ${ }^{5}$ The priority of schools and child care services may be correlated and the child care variable may capture the effect of schools. However, the estimate for school spending is not statistically significant. The effects of child care coverage, labor intensity and education of staff are largely unaffected by this extension.

It is evident from column $\mathrm{D}$ that coverage for younger and older children have similar effects. The estimated coefficient is somewhat higher for the older age group, reflecting that there are more cohorts than in the younger age group and that one additional place in child care will increase the coverage less for the older age group. The effect on house prices of one additional place in child care is almost identical for the two age groups.

Column E combines child care coverage for all children and children per man-year of staff and includes local government revenues as control. The effect of child care coverage now implies that $10 \%$-points higher coverage is associated with about $5 \%$ higher house prices. An increase in quality by one standard deviation will increase house prices by $3.5-4 \%$. The size of the effect is comparable to those shown for school capitalization (see overview of empirical

\footnotetext{
${ }^{5}$ Only available for 2002-2006.
} 
results by Black and Machin, 2011 and Davidoff and Leigh, 2008). The school studies find that one standard deviation difference in test scores is associated with $2-5 \%$ higher property values. It should be noticed that school capitalization effects disappear when better and more complicated measures of quality are investigated, such as the analysis of value-added rankings of schools by Imberman and Lovenheim (2016). Our measure of quality, children per employee in child care centers, is more readily observable and has had a lot of attention in the public debate.

In the rest of the paper we work with a simplified model that emphasizes child care coverage for all and where the indicator of quality is excluded. The reform was oriented towards coverage. As can be seen from column F, this simplification of the model has only negligible effect on the estimated effect of child care coverage and local government revenue.

Table 3

Pooled regression results, investigating population size, 2001-2006

\begin{tabular}{|c|c|c|c|c|c|}
\hline & All & $\begin{array}{c}\text { Above } \\
5000\end{array}$ & $\begin{array}{l}\text { Above } \\
10,000\end{array}$ & $\begin{array}{l}\text { Above } \\
20,000\end{array}$ & $\begin{array}{c}\text { Excluding } \\
3 \text { largest } \\
\text { cities }\end{array}$ \\
\hline Child care coverage, $1-5$ year & $\begin{array}{l}0.514 \\
(5.48)\end{array}$ & $\begin{array}{l}0.455 \\
(4.48)\end{array}$ & $\begin{array}{l}0.475 \\
(3.96)\end{array}$ & $\begin{array}{l}0.435 \\
(2.30)\end{array}$ & $\begin{array}{l}0.614 \\
(6.74)\end{array}$ \\
\hline $\begin{array}{l}\text { Local government revenue per } \\
\text { capita }\end{array}$ & $\begin{array}{l}0.377 \\
(3.60)\end{array}$ & $\begin{array}{l}0.583 \\
(2.88)\end{array}$ & $\begin{array}{l}0.592 \\
(6.13)\end{array}$ & $\begin{array}{l}0.596 \\
(2.29)\end{array}$ & $\begin{array}{l}0.409 \\
(4.53)\end{array}$ \\
\hline Community characteristics & Yes & Yes & Yes & Yes & Yes \\
\hline Housing characteristics & Yes & Yes & Yes & Yes & Yes \\
\hline Time fixed effects & Yes & Yes & Yes & Yes & Yes \\
\hline Month fixed effects & Yes & Yes & Yes & Yes & Yes \\
\hline Centrality fixed effects & Yes & Yes & Yes & Yes & Yes \\
\hline Labor market fixed effects & Yes & Yes & Yes & Yes & Yes \\
\hline Number of municipalities & 411 & 190 & 101 & 45 & 408 \\
\hline Number of obs & 307,710 & 299,115 & 281,660 & 245,064 & 183,580 \\
\hline $\mathrm{R}^{2}$ & 0.687 & 0.687 & 0.693 & 0.703 & 0.685 \\
\hline
\end{tabular}

Note: The dependent variable is the log of the housing price. T-values based on clustered standard errors (at the municipal level) in parentheses. Community characteristics include population size, age composition, settlement pattern, rate of unemployment, and winter temperature.

The population size of the municipalities is important, since the working of the housing market differs between small municipalities in rural areas and larger municipalities in urban areas. Both the level and growth of housing prices are lower in rural areas. The many small municipalities also have few housing transactions. We investigate the possible importance of these factors by excluding municipalities below 5000, 10,000, and 20,000 inhabitants 
respectively, and also by excluding the three largest cities Oslo, Bergen, and Trondheim. As shown in Table 3, the size of the capitalization effect for child care coverage is not much affected by the exclusion of small municipalities or the exclusion of the largest cities. The estimated coefficient for child-care coverage basically stays in the range 0.40-0.60.

The dataset consists of different types of houses, and the capitalization may vary between housing types. The analysis covers detached houses, semi-detached houses and apartments. Table 4 reports separate regressions for the three housing types to investigate the robustness. The sign of coverage is consistent across housing types, but the pricing of semi-detached houses and apartments seem less responsive to child care than detached houses. Possibly families with children are oriented towards detached houses. One the other hand, the pricing of semi-detached houses and apartments are somewhat more responsive to local government revenue. The residents in these house-types are possibly more affected by other services.

Table 4

Pooled regression results, different types of houses, 2001-2006

\begin{tabular}{l|cccc}
\hline & All & Detached & $\begin{array}{c}\text { Semi- } \\
\text { detached }\end{array}$ & Apartment \\
\hline Child care coverage, 1-5 year & 0.514 & 0.699 & 0.455 & 0.365 \\
& $(5.48)$ & $(7.28)$ & $(4.05)$ & $(2.71)$ \\
Local government revenue per & 0.377 & 0.469 & 0.563 & 0.541 \\
capita & $(3.60)$ & $(4.56)$ & $(4.96)$ & $(2.85)$ \\
& & & & \\
Community characteristics & Yes & Yes & Yes & Yes \\
Housing characteristics & Yes & Yes & Yes & Yes \\
Time fixed effects & Yes & Yes & Yes & Yes \\
Month fixed effects & Yes & Yes & Yes & Yes \\
Centrality fixed effects & Yes & Yes & Yes & Yes \\
Labor market fixed effects & Yes & Yes & Yes & Yes \\
Number of municipalities & 411 & 410 & 290 & 295 \\
Number of obs & 307,710 & 97,760 & 39,369 & 170,581 \\
$\mathrm{R}^{2}$ & 0.687 & 0.737 & 0.747 & 0.637 \\
\hline
\end{tabular}

Note: The dependent variable is the log of the housing price. T-values based on clustered standard errors (at the municipal level) in parentheses. Community characteristics include population size, age composition, settlement pattern, rate of unemployment, and winter temperature.

Additional robustness tests are presented in appendix $\mathrm{C}$ and $\mathrm{D}$. In table $\mathrm{C} 1$ we report results from year-by-year regressions. It follows that the estimated effect of child care coverage increases over time, while the effect of local government revenue is more stable. According to the 2006 estimate, an increase in child care coverage by $10 \%$-points will increase housing prices by $9.3 \%$. In table D1 we address housing characteristics and regional effects. 
Compared to earlier Norwegian studies (e.g. Borge and Rattsø 2014), we have access to fewer housing characteristics. In column A we control for the age of the houses, available only for the period 2003-2006. Both age and age squared come out as highly significant, but the effects of child care coverage and local government revenue are robust to this extension of the model. Columns B and $\mathrm{C}$ include respectively labor market area specific time trends and fixed effects for 83 economic regions. It follows that neither the sign nor the significance of child care coverage and local government revenue are affected by these modifications of the model.

\section{Alternative specification: Capitalization of changes in child care coverage}

The capitalization of child care services studied above is related to a national reform program to secure full coverage of children in child care centers. The main assumption for identification of capitalization effects is that the development of child care coverage is mandated from the central government and independent of local husing markets. However, the implementation of the program by the local governments open up for possible effects of local economic, social and political factors in the implementation. The standard sources of bias in this case may influence our results. The robustness of our results are investigated by the stronger assumption that only changes in the child care coverage were mandated. The analysis below estimates the model on first difference form.

The aim of the national child care reform starting in 2003 was to achieve full coverage of child care in the sense that all parents that demanded child care (and were willing to pay the regulated fee) should get a place. Full coverage was achieved around 2010 and our data set covers the first phase of the national reform. Our investigation of the identification strategy is based on the assumption that only the increased coverage from 2003 was mandated by the central government and therefore can be treated as exogenous. We estimate the following model using data for 2003 and 2006:

$\log \left(V_{h i t}\right)=\alpha_{t}+\alpha_{1}\left(C C_{i t}-C C_{i 2003}\right)+\alpha_{2} C C_{i 2003}+\alpha_{3} O S_{i t}+\alpha_{4} H_{h i t}+\alpha_{5} A_{i t}+v_{h i t}, t=2003,2006$

Model (2) can be interpreted as a specification where house values in 2003 are determined by child care coverage in 2003 and where house values in 2006 are determined by coverage in 
2003 plus the increased coverage from 2003 to 2006 . The parameter of interest is $\alpha_{1}$ that captures the effect of the mandated increase in coverage.

Table 5

Investigating the mandated increase in child care coverage from 2003 to 2006

\begin{tabular}{l|c}
\hline & A \\
\hline$\Delta$ Child care coverage 2003-2006 & 0.305 \\
& $(2.59)$ \\
Child care coverage 2003 & 0.717 \\
& $(7.57)$ \\
Local government revenue per capita & 0.358 \\
& $(3.29)$ \\
Community characteristics & Yes \\
Housing characteristics & Yes \\
Year fixed effects & Yes \\
Month fixed effects & Yes \\
Centrality fixed effects & Yes \\
Labor market fixed effects & Yes \\
& \\
Years & 2003,2006 \\
Number of municipalities & 400 \\
Number of obs & 119,956 \\
$\mathrm{R}^{2}$ & 0.700 \\
\hline
\end{tabular}

Note: The dependent variable is the log of the housing price. T-values based on clustered standard errors (at the municipal level) in parentheses.

Table 5 reports the estimation results. The estimate of $\alpha_{1}$ comes out as significant and with the expected positive sign. A mandated increase in child care coverage by $10 \%$-points, about one standard deviation, will increase house values by $3 \%$. This is lower than the corresponding estimate in the more general panel regressions above. The level effect captured by the estimate of $\alpha_{2}$ is more similar to the panel estimates (in particular the 2003 estimate in table $\mathrm{C} 1$ ). We conclude that the first-difference results are more convincing, and that the panel model is somewhat biased in the direction of overestimating the capitalization effect of child care coverage.

\section{Concluding remarks}

In this paper we analyze the local dimension of universal child care during a period of national reform to raise and equalize the child care coverage across local governments in 
Norway. We apply a rich dataset of housing transactions and characteristics for six years (2001-2006) and combine them with local government level data about quantity and quality of child care and various community controls. We conclude that child care reform is capitalized into housing markets and confirm the role of geographic sorting as part of local fiscal allocations.

\section{References}

Baker, M. (2011). Innis lecture: Universal early childhood interventions: what is the evidence base? Canadian Journal of Economics 44(4), 1069-1105.

Black, S. (1999). Do better schools matter? Parental valuation of elementary education. Quarterly Journal of Economics 114(2), 577-600.

Black, S., Devereux, P.J., Løken, K.V., \& Salvanes, K.G. (2014). Care or cash? The effect of child care subsidies on student performance. Review of Economics and Statistics 96(5), 824-837.

Bhuller, M.S. (2009). Inndeling av Norge i arbeidsmarkedsregioner (Classificiation of Norway in labor market regions). Memorandum 2009/24, Statistics Norway.

Black, S., \& Machin, S. (2011). Housing valuations of school performance. In E. Hanushek, E. Machin \& L. Woessman (Eds.), Handbook of the Economics of Education Vol 3. Amsterdam: North Holland.

Borge, L.-E., Brueckner, J., \& Rattsø, J. (2014). Partial fiscal decentralization and the demand responsiveness of the local public sector: Theory and evidence from Norway. Journal of Urban Economics 80, 153-163.

Borge, L.-E., \& Rattsø, J. (2014). Capitalization of property taxes in Norway. Public Finance Review 42(5), 635-661.

Brueckner, J.K. (1982). A test for allocative efficiency in the local public sector. Journal of Public Economics 19, 311-332.

Carlsen, F. (2005). Migration plans, local fiscal variables and local economic conditions. FinanzArchiv 61, 154-177.

Carlsen, F., Langset, B., \& Rattsø, J. (2005). The relationship between firm mobility and tax level: Empirical evidence of fiscal competition between local governments. Journal of Urban Economics 58, 273-288.

Carlsen, F., Langset, B., Rattsø, J., \& Stambøl, L. (2009). Using survey data to study capitalization of local public services. Regional Science and Urban Economics 39, 668-695.

Chetty, R., Friedman, J., Hilger, N., Saez, E., Schanzenbach, D., \& Yagan, D. (2011). How does your kindergarten classroom affect your earnings? Evidence from project STAR. Quarterly Journal of Economics 126, 1593-1660.

Clapp, J. M., Anupam, N., \& Ross, S.L. (2008). Which school attributes matter? The influence of school district performance and demographic composition on property values. Journal of Urban Economics 63, 451-466.

Davidoff, I., \& Leigh, A. (2008). How much do public schools really cost? Estimating the relationship between house prices and quality. Economic Record 84(265), 193-206.

Dehring, C.A., Depken II, C.A., \& Ward, M.R. (2008). A direct test of the homevoter hypothesis. Journal of Urban Economics 64, 155-178. 
Figlio, D., \& Lucas, M.E. (2004). What's in a grade? School report cards and the housing market. American Economic Review 94(3), 591-604.

Fischel, W.A. (2001a). The Homevoter Hypothesis: How home values influence local government taxation, school finance, and land-use policies. Cambridge MA: Harvard University Press.

Fischel, W.A. (2001b). Homevoters, municipal corporate governmance, and the benefit view of the property tax. National Tax Journal 54, 157-174.

Fiva, J.H., \& Kirkebøen, L. (2011). Information shocks and the dynamics of the housing market. Scandinavian Journal of Economics 113, 525-552.

Havnes, T., \& Mogstad, M. (2011a). Money for nothing? Universal child care and maternal employment. Journal of Public Economics 95(11-12), 1455-1465.

Havnes, T., \& Mogstad, M. (2011b). No child left behind: Subsidized child care and children's long run outcomes. American Economic Journal: Economic Policy 3(2), 97129.

Havnes, T., \& Mogstad, M. (2015). Is universal child care levelling the playing field? Journal of Public Economics 127, 100-114.

Hilber, C. (2017). The economic implications of house price capitalization: A synthesis. Real Estate Economics, forthcoming.

Hilber, C.A.L., \& and Mayer, C.J. (2009). Why do households without children support local public schools? Linking house price capitalization to school spending. Journal of Urban Economics 65(1), 74-90.

Imberman, S., \& Lovenheim, M.(2016). Does the market value value-added? Evidence from housing price after a public release of school and teacher value-added. Journal of Urban Economics 91, 104-121.

Jackson, C.K., Johnson, R., \& Persico, C. (2017). The effects of school spending on educational and economic outcomes: Evidence from school finance reforms. Quarterly Journal of Economics, forthcoming.

Langørgen, A., \& Løkken, S. (2017). Local government education spending and intergenerational mobility. Mimeo, Statistics Norway.

Machin, S., \& Salvanes, K.G. (2016), Valuing school quality via a school choice reform. Scandinavian Journal of Economic 118(1): 3-24.

Oates, W.E. (1969). The effects of property taxes and local public spending on property values: An empirical study of tax capitalization and the Tiebout hypothesis. Journal of Political Economy 77, 957-971.

Ross, S., \& Yinger, J. (1999). Sorting and voting: A review of the literature on urban public finance. In P. Cheshire \& E. Mils (Eds), Handbook of Urban and Regional Economics Vol 3. Amsterdam: North Holland.

Tiebout, C. (1956). A pure theory of local expenditures. Journal of Political Economy 64, 416-424.

Wallis, J.J., Sylla, R.E., \& Legler, J.B. (1994). The interaction of taxation and regulation in nineteenth century U.S. banking. In G. Goldin, and G.D. Libecap (Eds.), The Regulated Economy: A Historical Approach to Political Economy (pp. 121-144). Chicago IL: University of Chicago Press.

Wooldridge, J.M. (2003). Cluster-sample methods in applied econometrics. American Economic Review Papers and Proceedings 93, 133-138. 
Appendix A. Housing prices by municipal population size and part of country

Table A1

Housing prices (in NOK 1000) 2001 and 2006, grouped by municipal population size

\begin{tabular}{|c|c|c|c|c|c|c|}
\hline \multirow[t]{2}{*}{ Population } & \multicolumn{2}{|c|}{ Detached } & \multicolumn{2}{|c|}{ Semi-det./Row } & \multicolumn{2}{|c|}{ Apartments } \\
\hline & 2001 & 2006 & 2001 & 2006 & 2001 & 2006 \\
\hline Below 5,000 & 940 & 1206 & 837 & 1152 & 1101 & 1145 \\
\hline $5,000-10,000$ & 1139 & 1590 & 992 & 1379 & 1075 & 1261 \\
\hline $10,000-20,000$ & 1323 & 1868 & 1131 & 1571 & 1006 & 1316 \\
\hline $20,000-50,000$ & 1408 & 2154 & 1276 & 1788 & 1120 & 1385 \\
\hline 50,000 and above & 1954 & 3286 & 1613 & 2539 & 1224 & 1913 \\
\hline All houses & 1450 & 2262 & 1399 & 2117 & 1180 & 1763 \\
\hline
\end{tabular}

Table A2

Housing prices (in NOK 1000) 2001 and 2006, grouped by part of the country

\begin{tabular}{l|cc|cc|cc}
\hline \multirow{2}{*}{ Part of the country } & \multicolumn{2}{|c|}{ Detached } & \multicolumn{2}{c|}{ Semi-det./Row } & \multicolumn{2}{c}{ Apartments } \\
\hline The capital area & 2001 & 2006 & 2001 & 2006 & 2001 & 2006 \\
East inland & 1858 & 2983 & 1675 & 2587 & 1273 & 1972 \\
East coast & 1067 & 1479 & 998 & 1412 & 1006 & 1238 \\
South & 1371 & 1904 & 1167 & 1454 & 1127 & 1185 \\
West & 1425 & 2167 & 1241 & 1866 & 1078 & 1631 \\
Middle & 1500 & 2167 & 1298 & 2081 & 1115 & 1697 \\
North & 1210 & 1928 & 1321 & 2070 & 1106 & 1587 \\
\hline All houses & 1118 & 1960 & 900 & 1767 & 1092 & 1605 \\
\hline
\end{tabular}




\section{Appendix B. Estimated effects of housing characteristics}

\section{Table B1}

The effects of housing characteristics

\begin{tabular}{l|c}
\hline & Model A \\
Size $\left(\mathrm{m}^{2}\right)$ & Table 2 \\
Size squared & 0.0110 \\
& $(6.75)$ \\
Semi-detached or row house & -0.0000141 \\
& $(-22.64)$ \\
Apartment & 0.202 \\
& $(4.40)$ \\
& 0.404 \\
\hline
\end{tabular}

Note: The dependent variable is the log of the housing price. T-values based on clustered standard errors (at the municipal level) in parentheses. 


\section{Appendix C. Year-by-year regressions}

\section{Table C1}

Year-by-year regressions

\begin{tabular}{l|cccccc}
\hline & 2001 & 2002 & 2003 & 2004 & 2005 & 2006 \\
\hline Child care coverage 1-5 year & 0.428 & 0.499 & 0.603 & 0.758 & 0.816 & 0.933 \\
& $(2.99)$ & $(4.60)$ & $(6.15)$ & $(6.59)$ & $(5.63)$ & $(7.11)$ \\
Local government revenue & 0.279 & 0.442 & 0.354 & 0.354 & 0.545 & 0.376 \\
per capita & $(2.46)$ & $(3.77)$ & $(3.31)$ & $(2.55)$ & $(4.77)$ & $(3.12)$ \\
& & & & & & \\
Community characteristics & Yes & Yes & Yes & Yes & Yes & Yes \\
Housing characteristics & Yes & Yes & Yes & Yes & Yes & Yes \\
Year fixed effects & Yes & Yes & Yes & Yes & Yes & Yes \\
Month fixed effects & Yes & Yes & Yes & Yes & Yes & Yes \\
Centrality fixed effects & Yes & Yes & Yes & Yes & Yes & Yes \\
Labor market fixed effects & Yes & Yes & Yes & Yes & Yes & Yes \\
& & & & & & \\
Number of municipalities & 305 & 335 & 356 & 378 & 377 & 389 \\
Number of obs & 21,320 & 41,516 & 47,977 & 58,833 & 66,085 & 71,979 \\
$\mathrm{R}^{2}$ & 0.633 & 0.693 & 0.681 & 0.667 & 0.675 & 0.683 \\
\hline
\end{tabular}

Note: The dependent variable is the log of the housing price. T-values based on clustered standard errors (at the municipal level) in parentheses. 


\section{Appendix D. Robustness checks}

\section{Table D1}

Robustness checks

\begin{tabular}{l|ccc}
\hline & A & B & C \\
\hline Child care coverage 1-5 year & 0.717 & 0.573 & 0.268 \\
& $(8.18)$ & $(6.44)$ & $(2.62)$ \\
Local government revenue & 0.459 & 0.360 & 0.303 \\
per capita & $(4.44)$ & $(3.71)$ & $(3.18)$ \\
& & & \\
Modification & Age and age & Separate trend & Fixed effects for 83 \\
& squared & for each labor & economic regions \\
& & market region & \\
Community characteristics & & & \\
Housing characteristics & Yes & Yes & Yes \\
Year fixed effects & Yes & Yes & Yes \\
Month fixed effects & Yes & Yes & Yes \\
Centrality fixed effects & Yes & Yes & Yes \\
Labor market fixed effects & Yes & Yes & Yes \\
& & & No \\
Years & $2003-2006$ & $2001-2006$ & $2001-2006$ \\
Number of municipalities & 408 & 411 & 411 \\
Number of obs & 192,124 & 307,710 & 307,710 \\
R $^{2}$ & 0.730 & 0.695 & 0.694 \\
\hline
\end{tabular}

Note: The dependent variable is the log of the housing price. T-values based on clustered standard errors (at the municipal level) in parentheses. 


\section{Appendix E. Descriptive statistics}

Table E1

Descriptive statistics

\begin{tabular}{l|c}
\hline & $\begin{array}{c}\text { Mean } \\
(\text { st.dev })\end{array}$ \\
\hline Housing price (NOK) & 1651,889 \\
& $(91,677)$ \\
Area $\left(\mathrm{m}^{2}\right)$ & 101 \\
Child care coverage, 1-5 year & $(52)$ \\
Child care coverage, 1-2 year & 0.738 \\
Child care coverage, 3-5 year & $(0.110)$ \\
& 0.494 \\
Children per man-year & $(0.169)$ \\
Share of staff with child care education & 0.887 \\
Local government revenue per capita, adjusted for variation in & $(0.088)$ \\
spending needs, index where the weighted average equals 1 & 7.25 \\
each year & $(1.20)$ \\
School spending per pupil (NOK) & 0.309 \\
Population size & $(0.076)$ \\
Share of children, 0-6 years & $(0.224)$ \\
Share of elderly, 67 years and above & 74,652 \\
Share of population living in rural areas & $(16,677)$ \\
Unemployment rate & 9,858 \\
Winter temperature (Celsius) & $(29,583)$ \\
& 0.087 \\
& $(0.012)$ \\
& 0.152 \\
& $(0.033)$ \\
& 0.557 \\
& $(0.291)$ \\
& 0.031 \\
& $(0.015)$ \\
& -2.88 \\
& $(4.01)$ \\
\hline
\end{tabular}

